\title{
Reference Equations for Impulse Oscillometric and Respiratory System Model Parameters in Anglo and Hispanic Children
}

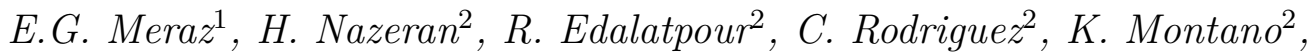 \\ C. Aguilar ${ }^{2}$, N. Avila ${ }^{2}$, J. O. Vidaña ${ }^{1}$, A. L. Portillo ${ }^{1}$ \\ ${ }^{1}$ Universidad Autónoma de Cd. Juárez, Cd. Juarez, México. \\ ${ }^{2}$ The University of Texas at El Paso, El Paso, Texas, USA.
}

\section{ABSTRACT}

The Impulse Oscillometry System (IOS) has been recognized as a useful diagnostic tool. Previous research by our group has shown that R5 (Resistance at $5 \mathrm{~Hz}$ ), R5-R20 (frequency dependence of resistance), AX (the "Goldman Triangle") and the extended Resistor-Inductor-Capacitor (eRIC) model-derived parameter Cp (peripheral Compliance) are reliable measures that track respiratory system function. Here we determined the predictive equations from 112 asthmatic and non-asthmatic Anglo and Hispanic children data, that were previously classified into four groups: Normal, PSAI (Probable Small Airway Impairment), SAI (Small Airway Impairment), and Asthma by using regression analysis of IOS and eRIC model parameters as dependent variables regressed against age, height, and weight. Height showed the greatest correlation with IOS and eRIC model parameters and provided the most significant reference values for these measures in Anglo and Hispanic children. These values could serve as a useful framework for diagnosis, early interventions, and treatment of respiratory diseases in this population.

Keywords: reference equations, impulse oscillometry, asthma, children, small airway impairment.

Correspondencia:

E. Meraz

Universidad Autónoma de Cd. Juárez, Cd. Juarez, México.

Correo electrónico: emeraz@uacj.mx
Fecha de recepción:

19 de noviembre de 2015

Fecha de aceptación: 29 de diciembre de 2015 


\section{RESUMEN}

El Sistema de Oscilometría Impulsos (por sus siglas en Inglés: IOS) ha sido reconocido como una herramienta de diagnóstico útil. Investigaciones previas realizadas por nuestro grupo han demostrado que R5 (Resistencia a $5 \mathrm{~Hz}$ ), R5-R20 (dependencia a la frecuencia de la resistencia), AX (el "Triángulo de Goldman") y el párametro Cp (Capacitancia periférica) derivado del modelo extendido Resistencia-inductor-condensador (eRIC) son medidas fiables que monitorean la función del sistema respiratorio. El presente estudio determina las ecuaciones de predicción de 112 niños Anglo e Hispanos asmáticos y no asmáticos, que previamente clasificados en cuatro grupos: Normal, PSAI (por su nombre en inglés: Probable daño en las vías aéreas menores), SAI (por su nombre en inglés: Daño en las vías aéreas menores), y Asma. Las ecuaciones de predicción se determinaron mediante análisis de regresión de parámetros del IOS y del modelo eRIC (variables dependientes) contra edad, estatura y peso. La estatura mostró la mejor correlación con los parámetros del IOS y del modelo eRIC, proporcionando los valores de referencia más significativos para estas medidas en niños Anglos e Hispanos. Estos valores podrían servir como un marco de refencia útil para el diagnóstico, intervenciones tempranas, y tratamiento de las enfermedades respiratorias en esta población.

Palabras clave: ecuaciones de referencia, oscilometría de impusos, asma, niños, daño en las vías aéreas menores.

\section{INTRODUCTION}

Asthma is caused by a combination of genetic and environmental factors. It is a syndrome comprising different signs and symptoms such as cough, wheezing, shortness of breath, and chest tightness (1). Asthma is one of the most common diseases of childhood, causing substantial morbidity (2). More than 10 million children in the USA under age 18 (14\%) have been diagnosed with asthma (3). According to Dorland's medical dictionary Small Airway Impairment (SAI) is a chronic obstructive bronchitis with narrowing of the bronchioles and small bronchi.

Pulmonary Function Testing (PFT) is of great importance in the evaluation and treatment of respiratory diseases. The advances in technology have culminated in the development of easier to use and commercially available PFT instruments that have been simplified in order to require minimal patient maneuvering and efforts (4).

Spirometry has been one of the most commonly used methods of assessing lung function in older children and adults (5). It has been demonstrated that both pre-school and school-age children have difficulty meeting some of the quality-control criteria outlined in the ATS/ERS guidelines when performing spirometry, and most pediatricians may profess that the critical period to evaluate pulmonary function is the infantile period, since this is the age of onset for childhood asthma (6). Objective measures for diagnosis and treatment of childhood asthma remain elusive (7), and the demand for an index applicable in a clinical setting for the evaluation of lung function in young children had been specified (8).

Forced Oscillation Technique (FOT) is the general name for airway mechanic measurement using the noninvasive superimposition of pressure waves on the subject's airway during normal tidal breathing. It has been noted however that a need for a practical FO index to define airway obstruction exists (9).

Impulse Oscillometry is one type of FOT. It is a promising pulmonary function testing 
method to diagnose and treat asthmatic preschoolers, but there is a need for more studies to be able to determine more precisely what IOS measures and what constitutes normal values (6-7). Impulse Oscillometry may be effectively employed in the diagnosis and management of diseases of the airways in children (10). IOS has also been recognized to be a useful diagnostic tool in early asthma development and could generate objective outcome measures of early interventions (1112). IOS should be considered as both an adjunct, and in some circumstances, as an alternative pulmonary function test to spirometry. It has been demonstrated that IOS has greater sensitivity and specificity in comparison to spirometry in identifying children with asthma and in determining their improvement after treatment on the basis of their bronchodilator responses (1214). Other studies have established that IOS could be used to detect alterations in airway mechanics over the course of therapy not reflected by spirometry and that IOS may be capable of demonstrating airway growthrelated changes over time (15-16).

Previous research by our group demonstrated that certain parameters of the equivalent electrical circuit models of the human respiratory system, the augmented RIC (aRIC) and extended RIC (eRIC), along with those of the IOS parameters have proven to be valuable in the diagnosis of patients with central and peripheral airway obstruction (16-17).

Reference Equations offer concise and compact quantitative means for evaluating the pulmonary function values of a single patient by comparing his or her data to the distribution of measurements in a reference population. Regression equations serve as effective and inexpensive alternatives to determine expected values of respiratory system measures as a function of height, weight, and age (18).

The purpose of this study was to determine predictive IOS Reference
Equations based upon data acquired from 112 asthmatic and non-asthmatic Anglo and Hispanic children, 5-17 years old, in order to provide an original frame of reference for different IOS and respiratory system model parameters within this population.

The present article is the first in publishing IOS Reference Equations for Anglo and Hispanic children 5 to 17 years old as well as the first in calculating Reference Equations for IOS-based respiratory system model parameters (eRIC-Rp and eRIC-Cp).

\section{METHODS}

\section{Subjects}

IOS pulmonary function testing was performed in Anglo and Hispanic children 5-17 years old living in El Paso, Texas. The data were collected at Western Sky Medical Research Clinic and at a Health Fair held at an elementary school located in the city's Socorro school district in 2006. The acquired data were then analyzed by our expert clinician and classified into four categories: Normal, Probable Small Airway Impairment (PSAI), Small Airway Impairment (SAI), and Asthma. A total of 112 children, 5 to 17 years of age were tested: 52 females and 60 males. The University of Texas at El Paso (UTEP) Institutional Review Board (IRB) approved the research protocol. An informed consent form was given to every parent and their child, providing them with a detailed description of the study. The study's population demographics (Age, Standing Height, and Weight) are shown in Table 1.

Table 1. Study Population

\begin{tabular}{ccc}
\hline & \multicolumn{2}{c}{ Demographics } \\
\hline & \multicolumn{2}{c}{ Males and Females } \\
\cline { 2 - 3 } Subject & Range & Mean \pm SD \\
\hline Age (years) & 5 to 17 & $9.88 \pm 3.62$ \\
Height $(\mathrm{cm})$ & 101.6 to 183.4 & $139.8 \pm 21.31$ \\
Weight $(\mathrm{kg})$ & 14.5 to 93.8 & $41.02 \pm 19.94$ \\
\hline
\end{tabular}




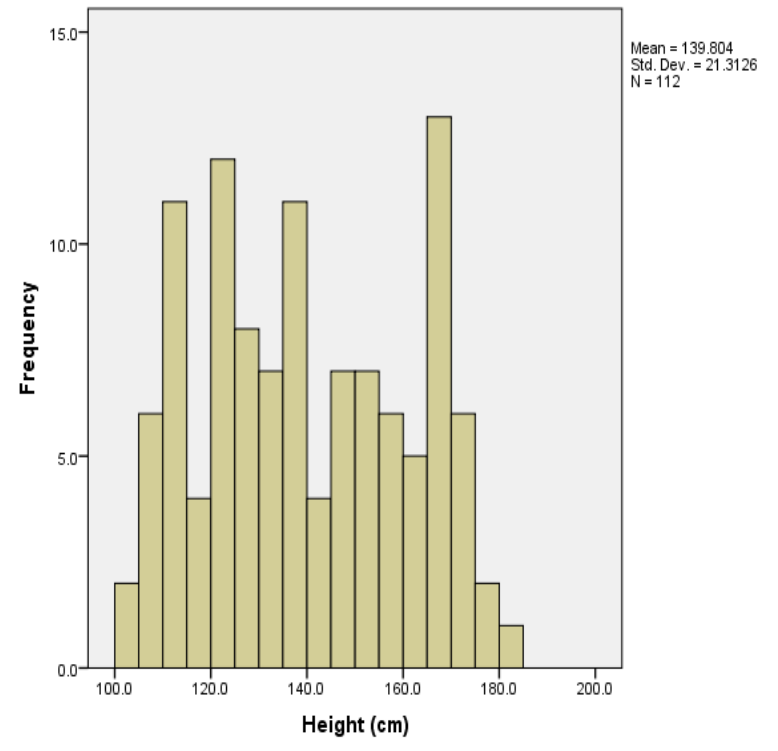

Figure 1. Histogram showing the distribution of the number of children with respect to their Heights.

Figure 1 shows the frequency distribution of all the study population as a function of Height $(\mathrm{cm})$.

\section{Regression equations}

Regression analysis was used in the determination of the Reference Equations for this population. The use of bivariate linear regressions provided the best prediction models with higher significance of independent variables, better than Multivariate linear equations.

One approach to perform regression analysis is to use separate simple regression equations for several different age groups. The square of the correlation coefficient $\left(\mathrm{r}^{2}\right)$ and the Standard Error of the Estimate (SEE) are the most common measures of how well the regression equations fit the data they describe. The proportion of variation in the observed data represented by the independent variables is measured by $r^{2}$. The SEE is the average Standard Deviation (SD) of the data around the regression line. As regression methods reduce the differences between the predicted and observed pulmonary function measures in the reference population, the values of SEE will decrease and $\mathrm{r}^{2}$ will increase (18).

\section{IOS measurements}

Impulse Oscillometry measures Pulmonary Impedance $(\mathrm{Zr})$ during normal tidal breathing of a subject. $\mathrm{Zr}$ is comprised of Resistance (R) and Reactance (X) components, which are 90 electrical degrees out of phase. Resistance is indicative of the energy required to propagate the pressure wave through the airways and Reactance is reflective of the amount of recoil generated against that pressure wave. The Reactance comprises forces of inertia resulting from the air movement in the conducting airways and the elastic recoil of the lung tissue. $\mathrm{R}$ and $\mathrm{X}$ are measured in either units of $\mathrm{cmH}_{2} \mathrm{O} / \mathrm{L} / \mathrm{s}$ or $\mathrm{KPa} / \mathrm{L} / \mathrm{s}$. IOS measures pulmonary function over a range of frequencies from 5 to 25 $\mathrm{Hz}$ (cycles/sec). Acoustic waves with lower oscillation frequencies, such as $5 \mathrm{~Hz}$, travel farther to the lung periphery and provide indices of the entire pulmonary system, whereas waves with higher frequencies, such as $20 \mathrm{~Hz}$, provide information primarily related to the central airways. Increasing evidence shows that the peripheral airways have an important role in asthma control; however none of the traditional tests (e.g. Spirometry) specifically measures the peripheral airways. IOS is increasingly being used to separately measure the degree of central and peripheral airway obstruction. Resistance at $5 \mathrm{~Hz}$ minus Resistance at 20 $\mathrm{Hz}$ (R5-R20) has been used as an index of frequency dependence of resistance (fdR), representing peripheral airways obstruction. Frequency dependence of resistance is inversely proportional to age: the younger the child, the greater the R5-R20 value $(10,19)$. The Resonant Frequency (Fres) is the point at which reactance is zero. The Reactance Area (AX), also called the "Goldman Triangle", is the integrated low frequency respiratory reactance magnitude between $5 \mathrm{~Hz}$ (X5) and Fres. AX is a single metric that reflects changes in the degree of peripheral airway obstruction and closely correlates with fdR (20). 
For this study, a Jaeger MasterScreen IOS (Viasys Healthcare, Inc. Yorba Linda, CA, USA) was used. The system was calibrated every day before data collection using a 3 -L syringe for volume calibrations and a reference resistance $(0.2 \mathrm{kPa} / \mathrm{L} / \mathrm{s})$ for pressure calibrations. Children were asked to wear a nose clip, while breathing normally through a mouthpiece, and were instructed to close their lips tightly around it to avoid air leakage. Three to five IOS test replicates were performed on each subject to ensure reproducible tests without artifacts caused by air leaks, swallowing, breath-holding, or vocalization. In each IOS test impulses were applied for a period of 30 to 45 seconds. IOS data were carefully reviewed offline and quality assured by our group's resident expert clinician who rejected segments affected by airflow leaks or swallowing artifacts.

\section{Respiratory Impedance Model}

\section{Extended RIC (eRIC) Model:}

This model was developed as an improvement to the RIC model with an additional peripheral Resistance (Rp) connected in parallel with the Capacitance. Therefore, the eRIC model is composed of central (large airway) Resistance (Rc), large airway Inertance (I), peripheral (small airway) Compliance (Cp), and peripheral (small airway) Resistance (Rp). This added $\mathrm{Rp}$ allows for the frequency dependence of Resistance observed in impedance data. Figure 2 shows the eRIC model circuit.

\section{Data analysis}

The average values of the IOS and eRIC model parameters were used in this study to determine the Regression Equations for the four groups: Normal, Probable Small Airway Impairment (PSAI), Small Airway Impairment (SAI), and Asthma. All of the statistical analyses in this study were performed using SPSS 22 Software (SPSS Inc., Chicago, IL, USA).

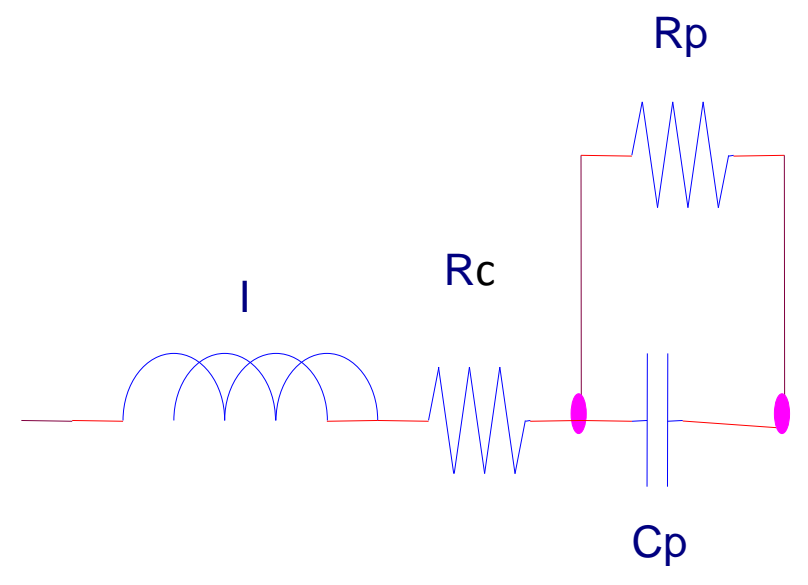

Figure 2. eRIC model (17).

These equations were generated using simple linear regression analysis with Height, Age, and Weight as independent variables.

\section{RESULTS}

Reference values are important indexes in establishing whether an individual's measured values fall within a range to be expected for a healthy person with similar height and age. Most of the previous studies performed to provide reference values for FOT and IOS parameters for children were designed for preschool children (21-28), as IOS has been proven to be of high significance in the assessment of the pulmonary system in this population. Attractive practical features such as: effort-free operation, minimal passive cooperation from the subject wearing a nose clip while keeping tightly closed lips around a mouthpiece, and breathing normally through the mouth make the IOS a popular lung function test for small children who are unable to perform spirometry. Studies by other researchers have generated FOT and IOS Reference Equations for 2-20 year-old children and young adults (29-33), which are comparable to the results in the present study.

Table 3 presents a summary of the studies performed using the Impulse Oscillometry technique to generate Reference Equations for children (23-28, 31-33). 
Table 2. Demographics for each classification group.

\begin{tabular}{cccc} 
Group & Age $($ years $)$ & Height $(\mathrm{cm})$ & Weight $(\mathrm{kg})$ \\
\hline Normal & 11 to 17 & $139.8-177.8$ & $32.7-84.7$ \\
PSAl & 5 to 17 & $122-175.3$ & $21.8-93.8$ \\
SAl & 5 to 17 & $104-183.4$ & $14.5-86$ \\
Asthma & 5 to 13 & $101.6-168.5$ & $16.8-83$ \\
\hline
\end{tabular}

Table 3. Summary of IOS Reference Equations for children.

\begin{tabular}{|c|c|c|c|c|c|c|}
\hline Technique & Author & Year & $\begin{array}{l}\text { Children Ages } \\
\text { and ethnicity }\end{array}$ & Equations & $r$ & $r^{2}$ \\
\hline 105 & $\begin{array}{c}\text { Malmberg } \\
n=109 \\
(23)\end{array}$ & 2002 & $\begin{array}{l}2.1-7.0 \text { years } \\
\text { Finnish children } \\
\text { (height in cm) }\end{array}$ & $\begin{array}{c}\operatorname{In}(R 5)=8.286-1.786^{*} \operatorname{In}(\text { Height }) \\
\ln (\mathrm{R} 20)=7.209-1.593^{*} \ln \text { (Height) } \\
\quad X 5=-4.069+0.806^{*} \ln (\text { Height })\end{array}$ & & $\begin{array}{l}0.530 \\
0.498 \\
0.564 \\
\end{array}$ \\
\hline 105 & $\begin{array}{c}\text { Frei } \\
n=222 \\
(24)\end{array}$ & 2005 & $\begin{array}{l}\text { 3-10 years } \\
\text { North American children } \\
\text { (height in } \mathrm{cm} \text { ) }\end{array}$ & $\begin{array}{l}R 5=2.11679-0.0099^{*} \text { Height } \\
R 20=1.45644-0.0065^{*} \text { Height } \\
X 5=-1.1974+0.00673^{*} \text { Height } \\
A X=10.9448-0.0684^{*} \text { Height }\end{array}$ & & $\begin{array}{l}0.435 \\
0.321 \\
0.219 \\
0.351 \\
\end{array}$ \\
\hline 105 & $\begin{array}{c}\text { Denker } \\
n=360 \\
(25)\end{array}$ & 2006 & $\begin{array}{l}2.1 \text { - } 11.1 \text { years } \\
\text { Finnish and } \\
\text { Sweedis } h \text { children } \\
\text { (height in } \mathrm{m} \text { ) } \\
\end{array}$ & $\begin{array}{c}R 5=0.266+0.759^{*} \text { Height }{ }^{\wedge}(-3)+0.004^{*} \text { weight } \\
R 20=0.259+0.630^{*} \text { Height }^{\wedge}(-3) \\
X 5=-0.123-0.255^{*} \text { Height }^{\wedge}(-3)\end{array}$ & & \\
\hline 105 & $\begin{array}{c}\text { Park } \\
\mathrm{n}=119 \\
(26)\end{array}$ & 2011 & $\begin{array}{l}\text { 3-6 years } \\
\text { Korean children } \\
\text { (height in cm) }\end{array}$ & $\begin{array}{l}R 5=1.934-0.009^{*} \text { Height } \\
R 10=1.516-0.007^{*} \text { Height } \\
X 5=-0.675+0.004^{*} \text { Height } \\
A X=6.368-0.041^{*} \text { Height }\end{array}$ & $\begin{array}{l}0.348 \\
0.337 \\
0.34 \\
0.337 \\
\end{array}$ & $\begin{array}{l}0.121 \\
0.114 \\
0.116 \\
0.113 \\
\end{array}$ \\
\hline 105 & $\begin{array}{l}\text { Lee } \\
n=161 \\
(27)\end{array}$ & 2012 & $\begin{array}{l}\text { 3-7 years } \\
\text { Korean children } \\
\text { (age in months) } \\
\text { (height in cm) }\end{array}$ & $\begin{array}{c}\text { R5 }=2.242-0.008^{*} \text { Height }-0.005^{*} \text { age } \\
\text { R20 }=1.518-0.007^{*} \text { Height } \\
\text { X5 }=-0.921+0.005^{*} \text { Height }\end{array}$ & & $\begin{array}{l}0.213 \\
0.132 \\
0.091\end{array}$ \\
\hline 105 & $\begin{array}{l}\text { Lai } \\
\text { (28) }\end{array}$ & 2015 & $\begin{array}{l}\text { 2-6 years } \\
\text { Taiwanes e children } \\
\text { (height in } \mathrm{cm} \text { ) }\end{array}$ & $\begin{array}{c}R 5=2.4395-0.0134^{*} \text { Height } \\
R 20=1.3888-0.0069^{*} \text { Height } \\
X 5=-0.6408+0.0036^{*} \text { Height } \\
\quad A X=10.4286-0.0686\end{array}$ & $\begin{array}{l}0.280 \\
0.150 \\
0.100 \\
0.139 \\
\end{array}$ & \\
\hline 105 & $\begin{array}{l}\text { Amra } \\
n=509 \\
(31)\end{array}$ & 2008 & $\begin{array}{l}\text { 5-19 years } \\
\text { Iranian children } \\
\text { (age in years) } \\
\text { (height in cm) }\end{array}$ & 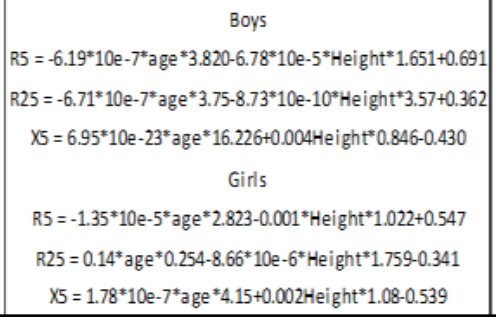 & & $\begin{array}{l}0.270 \\
0.180 \\
0.230 \\
0.040 \\
0.010 \\
0.030\end{array}$ \\
\hline 105 & $\begin{array}{l}\text { Nowowiejska } \\
n=626 \\
(32)\end{array}$ & 2008 & $\begin{array}{l}\text { 3.1-18.9 years } \\
\text { Polish children } \\
\text { (age in years) } \\
\text { (height in cm) }\end{array}$ & $\begin{array}{l}R 5=\exp \left(1.818-0.0169^{*} \text { Height }\right) \\
R 20=\exp \left(1.217-0.0148^{*} \text { Height }\right) \\
X 5=\exp \left(-0.728+0.0037^{*} \text { Height }\right)\end{array}$ & $\begin{array}{l}0.873 \\
0.842 \\
0.845\end{array}$ & \\
\hline 105 & $\begin{array}{c}\text { Gochicoa-Rangel } \\
n=283 \\
\text { (33) }\end{array}$ & 2015 & $\begin{array}{l}\text { 2.7-15.4 years } \\
\text { Mexican children } \\
\text { (age in years) } \\
\text { (height in cm) }\end{array}$ & $\begin{array}{c}\text { Boys } \\
R 5=-0.636^{*} \log (\text { Age })+99.506^{*}(1 / \text { Height })+0.443 \\
\text { R20 }=-0.367^{*} \log (\text { Age })+82.162^{*}(1 / \text { Height })+0.140 \\
X 5=0.228^{*} \log (\text { Age })-46.787^{*}(1 / \text { Height })-0.068 \\
\text { AX }=-3.938^{*} \log (\text { Age })+340.493^{*}(1 / \text { Height })+2.635 \\
\text { Girls } \\
\text { R5 }=-0.736^{*} \log (\text { Age })+78.861^{*}(1 / \text { Height })+0.702 \\
\text { R20 }=-0.427^{*} \log (\text { Age })+69.880^{*}(1 / \text { Height })+0.307 \\
X 5=0.309^{*} \log (\text { Age })-42.906^{*}(1 / \text { Height })-0.185 \\
\text { AX }=-2.345^{*} \log (\text { Age })+640.548^{*}(1 / \text { Height })-1.212\end{array}$ & $\begin{array}{l}-0.86 \\
-0.87 \\
0.79 \\
-0.78 \\
-0.89 \\
-0.89 \\
0.85 \\
-0.83\end{array}$ & \\
\hline
\end{tabular}


A recent study by Hagiwara et al. (34) was published showing Reference Values for Japanese Children (6-15 years). In this study the authors presented R5, R20 and R5-R25 Reference values according to height in terms of standard deviation calculated with the lambda-mu-sigma (LMS) method. As only IOS Reference values and standard curves, for the mentioned parameters, were presented and Reference Equations were not calculated, as in previous studies (21-33), it was not possible for us to include that study in our Table 3.

Also Santos Schivinski et al. (35) recently reported IOS Reference Equations for Brazilian Healthy children and adolescents. They tested 864 healthy school students aged 6 to 14 years old. Only an abstract has been published on this research and no Reference Equations were given.

In our previous work, we have demonstrated that there are no significant differences between genders (36) and between ethnic groups in this population (37). We did not observe gender or race significant differences in the same manner in our investigation as it was demonstrated in previous studies $(24-25,27)$.

In the present study Reference Equations for IOS and eRIC model parameters were generated based upon IOS data acquired from 112 children, previously classified by our expert clinician, the late Dr. Michael Goldman, into four groups: Normal, PSAI, SAI and Asthma. The Normal Group was composed of 11 children, PSAI of 17 children, SAI of 54 children and Asthmatic of 30 children, respectively. In Table 2, the demographics for each group are presented.

In Table 3 the following information is presented: $\mathrm{r}=$ correlation coefficient, $r^{2}=$ coefficient of determination (the fraction of the data that is the closest to the line of best fit), $\mathrm{R}=$ Resistance $(\mathrm{kPa} / \mathrm{L} / \mathrm{s})$, $\mathrm{X}=$ Reactance $(\mathrm{kPa} / \mathrm{L} / \mathrm{s}), \quad \mathrm{AX}=$ the Goldman Triangle $(\mathrm{kPa} / \mathrm{L})$, Height (meters or centimeters), Age (years or months), and
Table 4. Regression equations for normal group. Height $(\mathrm{cm})$

\begin{tabular}{|c|c|c|}
\hline Normal $(n=11)$ & $r^{2}$ & SEE \\
\hline R5 $=1.428-0.006 *$ Height & 0.647 & 0.05578 \\
\hline R10 $=1.313-0.006 *$ Height & 0.597 & 0.05808 \\
\hline R15 $=1.304-0.006 *$ Height & 0.604 & 0.05714 \\
\hline R20 $=1.072-0.005^{*}$ Height & 0.473 & 0.05721 \\
\hline R25 $=.979-0.004 *$ Height & 0.370 & 0.06105 \\
\hline$X 5=-0.340+0.001 *$ Height & 0.151 & 0.04053 \\
\hline $\mathrm{X} 10=-0.086+0.0003 *$ Height & 0.072 & 0.01655 \\
\hline$X 15=-0.152+0.001 *$ Height & 0.232 & 0.02279 \\
\hline$X 20=-0.042+0.001 *$ Height & 0.080 & 0.02648 \\
\hline $\mathrm{X} 25=0.301-0.001 *$ Height & 0.211 & 0.02541 \\
\hline R5-R20 $=0.345-0.002 *$ Height & 0.402 & 0.02458 \\
\hline Fres $=27.589-0.088^{*}$ Height & 0.165 & 2.39063 \\
\hline$A X=1.213-0.005 *$ Height & 0.241 & 0.11026 \\
\hline eRIC-Rp $=0.704-0.002 *$ Height & 0.034 & 0.13547 \\
\hline eRIC-Cp $=-0.327+0.003 *$ Height & 0.301 & 0.05770 \\
\hline
\end{tabular}

Table 5. Regression equations for PSAI group.

\begin{tabular}{lcc} 
PSAI $(n=17)$ & $r^{2}$ & SEE \\
\hline R5 $=1.249-0.005^{*}$ Height & 0.648 & 0.06881 \\
R10 $=0.976-0.004 *$ Height & 0.534 & 0.06517 \\
R15 $=0.756-0.002^{*}$ Height & 0.246 & 0.07312 \\
R20 $=0.714-0.002^{*}$ Height & 0.271 & 0.07305 \\
R25 $=0.905-0.003^{*}$ Height & 0.468 & 0.07040 \\
X5 $=-0.710+0.004 *$ Height & 0.820 & 0.03135 \\
X10 $=-0.363+0.002^{*}$ Height & 0.647 & 0.02648 \\
X15 $=-0.211+0.001^{*}$ Height & 0.421 & 0.02680 \\
X20 $=0.082+0.0002^{*}$ Height & 0.038 & 0.02487 \\
X25 $=0.295-0.001 *$ Height & 0.439 & 0.02538 \\
R5-R20 = 0.530-0.003*Height & 0.486 & 0.04971 \\
Fres $=23.142-0.042^{*}$ Height & 0.158 & 1.84298 \\
AX $=4.426-0.023 *$ Height & 0.724 & 0.27173 \\
eRIC-Rp = 2.023-0.010*Height & 0.777 & 0.10460 \\
eRIC-C $=-0.141+0.002^{*}$ Height & 0.628 & 0.02410 \\
\hline
\end{tabular}

Weight (kilograms) for the mentioned studies using IOS (23-28, 31-33).

Our linear regression analysis indicated that IOS variables were well correlated with both Height and Age, as found by Amra (31) and Gochioca-Rangel (33), but most strongly associated with Height as has been shown in previous studies (23-29, 32). The Reference Equations generated in the present study as a function of Height are presented in Table 
Table 6. Regression equations for SAI group.

\begin{tabular}{|c|c|c|}
\hline SAI $(n=54)$ & $r^{2}$ & SEE \\
\hline R5 $=1.328-0.005 *$ Height & 0.435 & 0.10992 \\
\hline R10 $=0.925-0.003 *$ Height & 0.265 & 0.09678 \\
\hline R15 $=0.643-0.002 *$ Height & 0.080 & 0.10325 \\
\hline R20 $=0.623-0.002 *$ Height & 0.103 & 0.09301 \\
\hline R25 $=0.831-0.003 *$ Height & 0.321 & 0.08004 \\
\hline$X 5=-0.785+0.004 *$ Height & 0.670 & 0.05233 \\
\hline$X 10=-0.502+0.003 *$ Height & 0.562 & 0.04367 \\
\hline$X 15=-0.314+0.002 *$ Height & 0.473 & 0.03352 \\
\hline$X 20=0.039+0.0001 *$ Height & 0.003 & 0.04706 \\
\hline$X 25=0.197-0.001 *$ Height & 0.067 & 0.04551 \\
\hline R5-R20 $=0.704-0.003^{*}$ Height & 0.509 & 0.06336 \\
\hline Fres $=21.066-0.013^{*}$ Height & 0.010 & 2.45177 \\
\hline$A X=5.936-0.030 *$ Height & 0.592 & 0.48159 \\
\hline eRIC-Rp $=1.9002-0.009 *$ Height & 0.558 & 0.16099 \\
\hline eRIC-Cp $=-0.076+0.001 *$ Height & 0.506 & 0.01969 \\
\hline
\end{tabular}

Table 7. Regression equations for asthma group.

\begin{tabular}{|c|c|c|}
\hline Asthma $(n=30)$ & $r^{2}$ & SEE \\
\hline R5 = $1.684-0.007 *$ Height & 0.557 & 0.11314 \\
\hline R10 $=1.164-0.004 *$ Height & 0.451 & 0.08689 \\
\hline R15 $=0.854-0.003 *$ Height & 0.261 & 0.08669 \\
\hline$R 20=0.680-0.002 *$ Height & 0.150 & 0.08075 \\
\hline R25 $=0.781-0.002 *$ Height & 0.226 & 0.07696 \\
\hline$X 5=-1.036+005 *$ Height & 0.683 & 0.06752 \\
\hline$X 10=-0.661+0.003 *$ Height & 0.634 & 0.04709 \\
\hline$X 15=-0.484+0.002 *$ Height & 0.631 & 0.03612 \\
\hline$X 20=-0.144+0.001 *$ Height & 0.161 & 0.04019 \\
\hline$X 25=0.194-0.001 *$ Height & 0.099 & 0.04161 \\
\hline R5-R20 $=1.004-0.005 *$ Heght & 0.607 & 0.07466 \\
\hline Fres $=24.184-0.025 *$ Height & 0.081 & 1.62774 \\
\hline$A X=8.764-0.045 *$ Height & 0.720 & 0.52861 \\
\hline eRIC-Rp $=2.263-0.011^{*}$ Height & 0.618 & 0.16554 \\
\hline eRIC-Cp $=-0.035+0.001 *$ Height & 0.675 & 0.00769 \\
\hline
\end{tabular}

4 for Normal, Table 5 for PSAI, Table 6 for SAI, and Table 7 for Asthmatic children respectively; where $r^{2}=$ the coefficient of determination and SEE $=$ the Standard Error of the Estimate.

\section{DISCUSSION}

In contrast to our research, the study performed by Frei et al. (24), presented

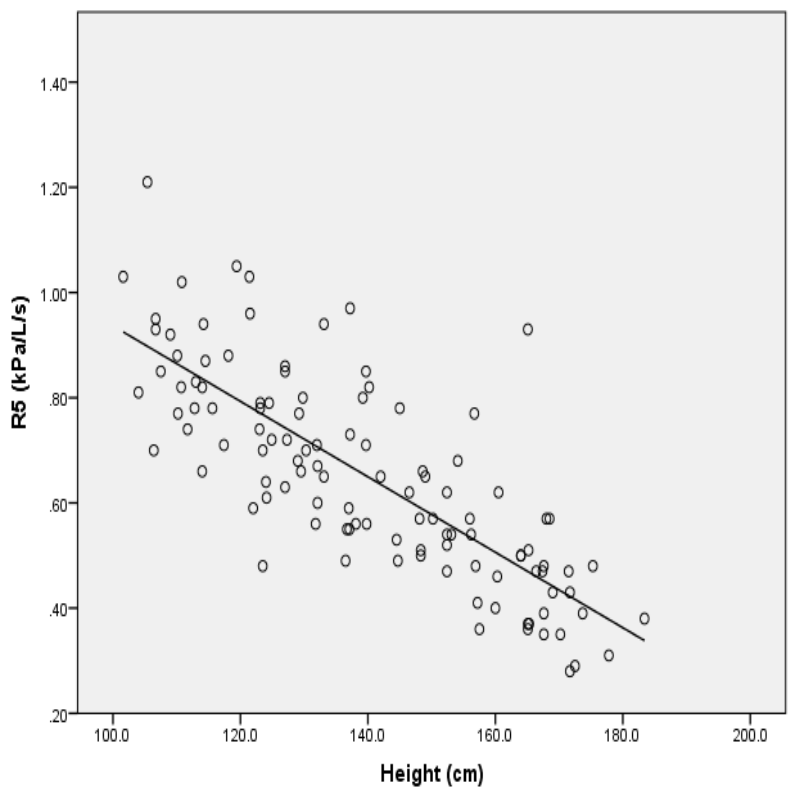

Figure 3. R5 as function of Height for all children.

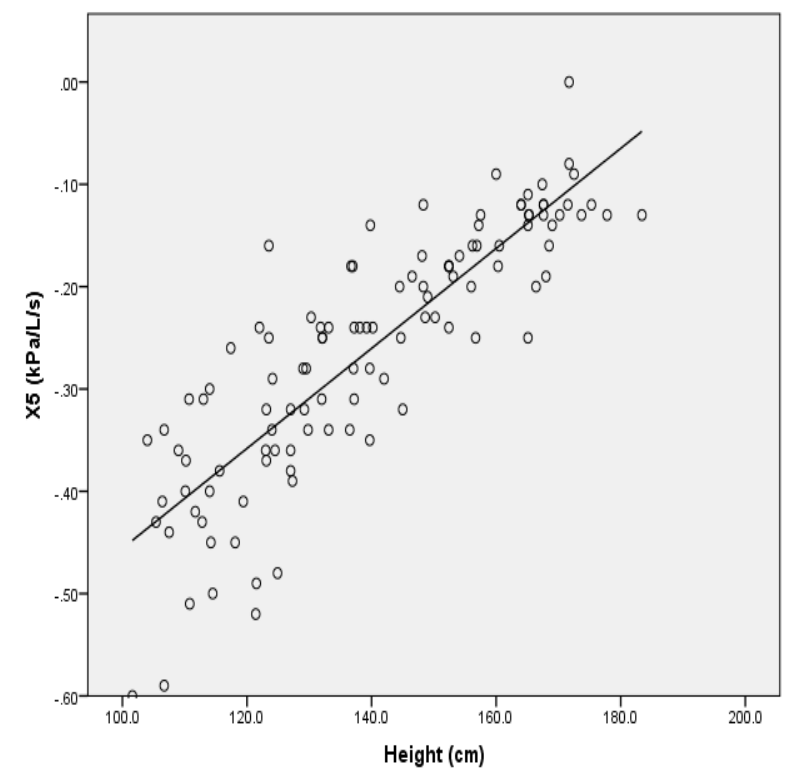

Figure 4. X5 as function of height for all children.

Reference Equations for solely white North American children (3-10 years) with two white parents.

Our study is the first in publishing IOS Reference Equations for Anglo and Hispanic children 5 to 17 years old. Also is the first study in calculating Reference Equations for IOS-based respiratory system model parameters (eRIC-Rp and eRIC-Cp). One of the advantages of our Reference Equations is that most of the significant IOS and model parameters resulted in $r^{2}$ values 
higher than $30 \%$, with some of them reaching up to $60 \%$ and even to $80 \%$, whereas previous studies reported $r^{2}$ values lower than $20 \%$ (26-27).

The regression equations with $r^{2}$ values higher than 0.4 are highlighted in bold in Tables 4 to 7 . In the Normal Group, it can be observed that the resistance values R5 to R20 and R5-R20 present the highest $r^{2}$ values, showing these to be good predictors of normal parameters. In the PSAI, SAI, and Asthma Groups R5, X5, X10, X15, R5-R20, AX eRIC-Rp and eRIC$\mathrm{Cp}$ have the greatest $r^{2}$ values which seem to indicate that these parameters are the best predictors for children with respiratory impairments. These results seem to confirm what Nowowiejska et al. have previously concluded (32) by showing that reactances manifested greater specificity compared to resistances in assessing bronchial obstruction in children.

One of the limitations of our study was that the Normal Group included solely sample data from children 11-17 years old. This could be the reason why our R5 regression coefficient was lower than those reported in previous studies by other researchers (24-27). However, in spite of this limitation, it is clear that Resistance values decrease with Height and Age as expected.

In Figure 5, the reference equation for R5 as a function of Height was compared with those generated in previous studies, which utilized simple linear regression equations to represent their data. Our data are close to those acquired by Nowowiejska et al. (32), who utilized a wider age range than the ones used in other studies, and it seems that the equations generated by Frei et al. (24), Park et al. (26), and Lai et al. (28) could have been similar to ours if we would have been able to include data from younger normal children with lower heights.

It can be observed in Figures 6 and 7 that R5 increases with respiratory impairment severity, from normal to PSAI to SAI and

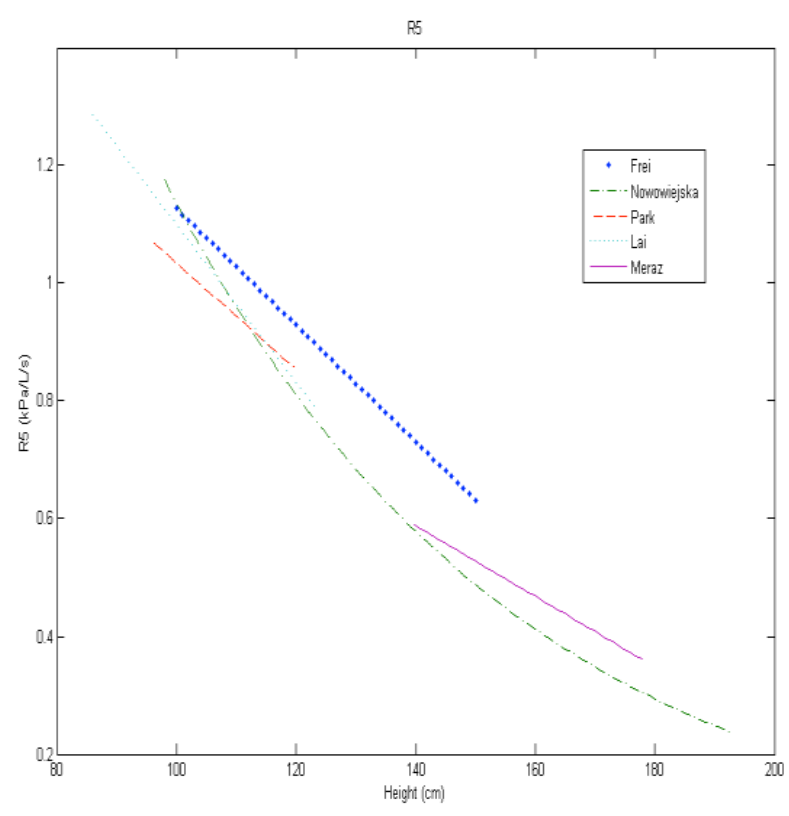

Figure 5. A comparison of the relationship between R5 and Height in our study and those of Frei, Park, Lai and Nowowiejska(24, 26, 28, 32).

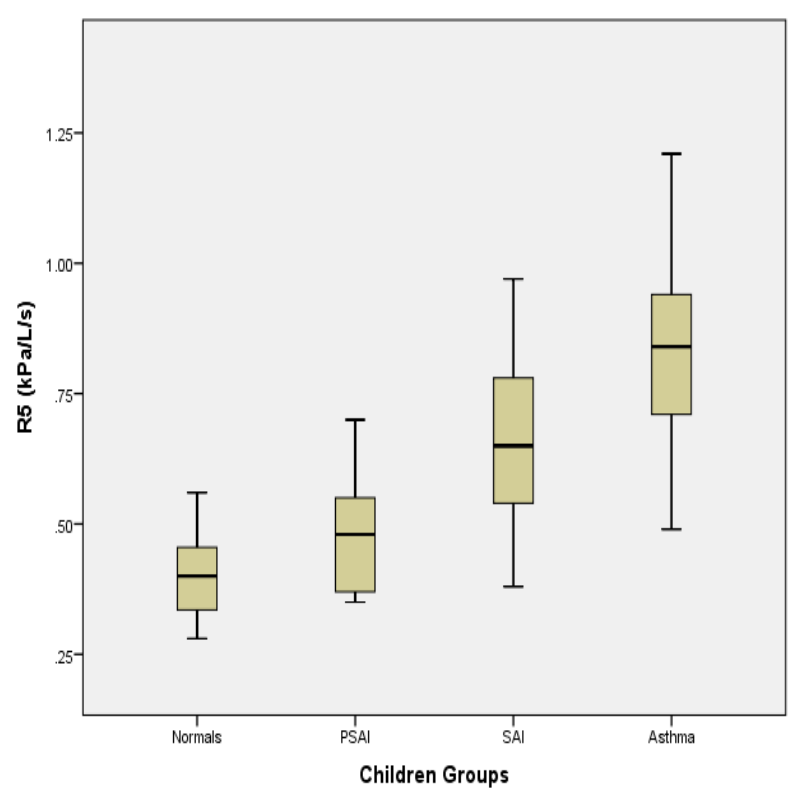

Figure 6. R5 Boxplot for the four groups in our study population.

Asthma. It can also be noticed that X5 decreases with SAI and Asthma severity, in the same progression as expected. In a similar manner, Figure 8 shows that AX increases with respiratory impairment severity. 


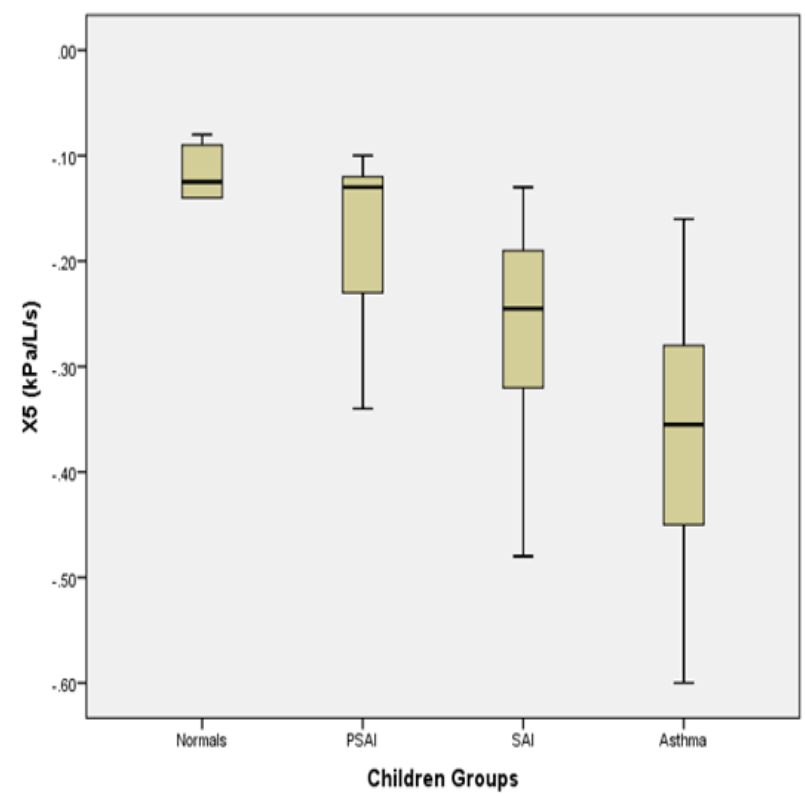

Figure 7. X5 Boxplot for the four groups in our study population.

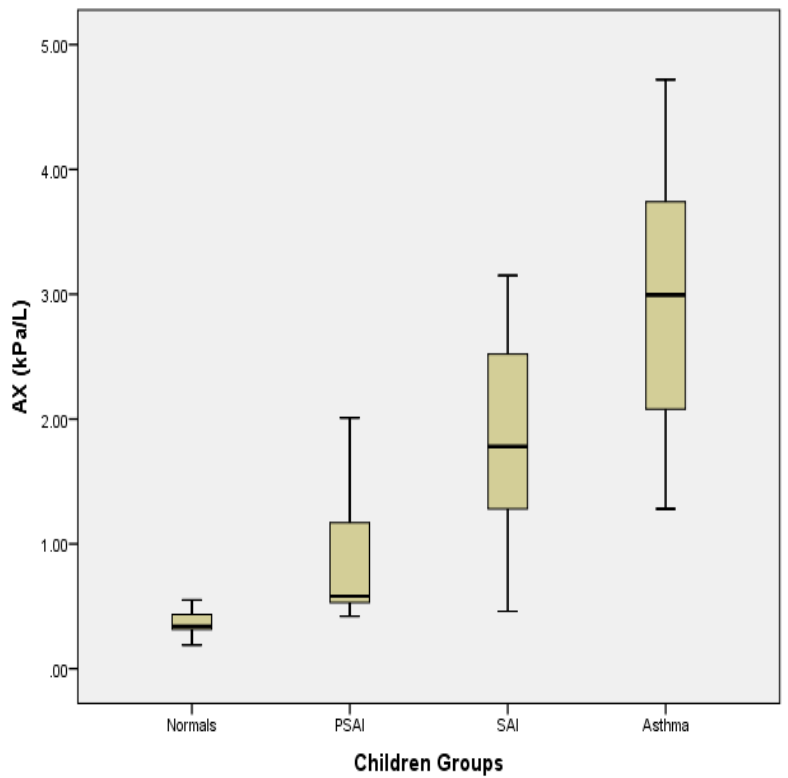

Figure 8. AX Boxplot for the four groups in our study population.

\section{CONCLUSIONS}

Impulse Oscillometry can serve as a sensitive pulmonary function test performed in younger and older children to diagnose asthma and other pulmonary conditions with relative ease and without requiring extreme breathing maneuvers and bronchoprovocation. It has been proven to be useful in the assessment of respiratory impairments. Our investigation reported here provided IOS and eRIC model parameter Reference Equations for four groups of Hispanic and Anglo children: Normal, PSAI, SAI and Asthma. These equations could be used in the future to provide a quantitative framework for indication of illness progression, or as a reference tool to diagnose the degree of respiratory system impairments in children in the 5 - 17 year-old age group.

This work showed and validated that Height was the best determinant of IOS variables. Resistance $(\mathrm{R})$ correlated negatively with Height, while Reactance (X) correlated positively as previously seen in the literature.

\section{Acknowledgements}

The data collection for this research was supported by NIH grant \#1 S11 ES013339001 A 1: UTEP-UNM HSC ARCH Program on Border Asthma. HN and EGM would like to dedicate this contribution to the loving memory of Dr. Michael Goldman, Professor of Medicine at the UCLA Medical School. We will remain eternally thankful for his mentoring in Pulmonary Physiology, FOT and IOS testing, for his collaboration, and friendship. He will always be present in our work and our hearts.

\section{REFERENCES}

1. Panettieri R.A. Jr, Covar R, Grant E, Hillyer E.V., Bacharier L. "Natural history of asthma: Persistence versus progression - does the beginning predict the end?" American Academy of Allergy, Asthma \&6 Immunology, vol. 121, no. 3, pp. 607-613.

2. Asher M.I., Keil U., Anderson H.R., Beasley R., Crane J., Martinez F., 
Mitchell E.A., Pearce N., Sibbald B., Stewart A.W., Strachan D., Weiland S.K., Williams H.C. "International study of asthma and allergies in childhood (ISAAC): rationale and methods." European Respiratory Journal, vol. 8, pp. 483-491.

3. Bloom B, Jones LI, Freeman G. "Summary health statistics for U.S. children: National Health Interview Survey 2012," National Center for Health Statistics, Vital Health Stat vol. 10, no. 258, Hyattsville, Maryland, 2013.

4. Escobar H., Carver T.W. "Pulmonary function testing in young children." Current Allergy and Asthma Reports, vol. 11, pp. 473- 481, 2011.

5. Larsen G.L., Brian Kang JK., Guildbert T., Morgan W. "Assessing respiratory function in young children: Developmental considerations." American Academy of Allergy, Asthma and Immunology, vol. 115, no. 4, pp. 657-666, 2005.

6. Mochizuki H, Hirai K, Tabata H. "Forced oscillation technique and childhood asthma." Allergology International, vol. 61, pp. 373-383, 2012 .

7. Galant SP, Nickerson B. "Lung function measurement in the assessment of childhood asthma: recent important developments." Current Opinion in Allergy and Clinical Immunology, vol. 10, pp. 149-154, 2010.

8. Bisgaard H, Klug B. Lung function measurement in awake young children." Eur Respir J, vol. 8, pp. 2067-2075, 1995.

9. Oostveen E, MacLeod D, Lorino H, Farre R, Hantos Z, Desager $\mathrm{K}$, Marchal F, "On behalf of the
ERS Task Force on Respiratory Impedance Measurements. The forced oscillation technique in clinical practice: methodology, recommendations and future developments." Eur Respir J, vol. 22, pp. 1026-1041, 2003.

10. Komarow HD, Myles IA, Uzzaman A, Metcalfe DD. "Impulse oscillometry in the evaluation of diseases of the airways in children." Ann Allergy Asthma Immunol, vol. 106, no. 3, pp. 191-199, 2011.

11. Marota A, Klinnert MD, Price MR, Larsen GL, Liy AH. "Impulse oscillometry provides an effective measure of lung dysfunction in 4year-old children at risk for persistent asthma." J Allergy Clin Immunol, vol. 112, no. 2, pp. 317-321, 2003.

12. Song TW, Kim KW, Kim ES, Park J-W, Sohn MH, Kim K-E. "Utility of impulse oscillometry in young children with asthma." Pediatr Allergy Immunol, vol. 19, pp. 763-768, 2008.

13. Gaylor PB, Saadeh CK, Goldman MD, Malacara JM, McGee MN. "Forced oscilation using Impulse Oscillometry (IOS) provides objective responses to Inhaled Corticosteroid (ICS) in asthmatic patients when FEV1 fails to improve." J Allergy and Clin Immun, vol. 111, art. S135, 2003.

14. Komarow HD, Skinner J, Young M, Gaskins D, Nelson C, Gergen PJ, Metcalfe DD. "A study of the use of impulse oscillometry in the evaluation of children with asthma: analysis of lung parameters, order effect, and utility compared with spirometry." Pediatr Pulmonol, vol. 47, no. 1, pp. 18-26, 2012.

15. Larsen GL, Morgan W, Heldt GP, Mauger DT, Boehmer SJ, Chinchilli VM, Lemanske RF, Martinez F, Strunk 
RC, Szefler SJ, Zeiger RS, Taussig LM, Bacharier LB, Guilber TW, Radford $\mathrm{S}$, Sorkness CA. "Impulse oscillometry versus spirometry in a long-term study of controller therapy for pediatric asthma." J Allergy Clin Immunol, vol. 123, no. 4, pp. 861-867, 2009.

16. Meraz EG, Nazeran H, Ramos CD, Nava P, Diong B, Goldman MD. "Analysis of impulse oscillometric measures of lung function and respiratory system model parameters in small airway-impared and healthy children over a 2 year period." Biomedical Engineering Online Journal, vol. 10, pp. 1-21, 2011.

17. Diong B., Nazeran H., Nava P., Goldman M.D. "Modeling human respiratory impedance." IEEE Engineering in Medicine and Biology Magazine, vol. 26, no. 1, pp. 48-55, 2007.

18. American Thoracic Society. "Lung function testing: selection of reference values and interpretative strategies." American Review of Respiratory Disease, vol. 144, no. 5, pp. 1202-1218, 1991.

19. Yixin S., Aledia A.S., Galant S.P., George S.C. "Peipheral airway impairment measured by oscillometry predicts loss of asthma control in children." American Academy of Allergy, Asthma \& Immunology, vol. 131, no. 3, pp. 718-723, 2012.

20. Smith H.J., Reinhold P. Goldman M.D. "Forced oscillation technique and impulse oscillometry." Eur Respir Mon, vol. 31, pp. 72-105, 2005.

21. Klug B, Bisgaard H. "Specific airway resistance, interrupter resistance, and respiratory impedance in healthy children aged 2-7 years." Pediatr Pulmonol, vol. 25, pp. 322-331, 1998.
22. Hellinckx J, De Boeck K, BandeKnops J, van der Poel M, Demedts M. "Bronchodilator response in 3-6.5 year old healthy and stable asthmatic children." Eur Respir J, vol. 12, pp. 438-443, 1998.

23. Malmberg LP, Pelkonen A, Poussa T, Pohjanpalo A, Haahtela T, Turpeinen M. "Determinants of respiratory system input impedance and bronchodilator response in healthy Finnish preschool children." Clin Physiol \& Func Im, vol. 22, pp. 64-71, 2002.

24. Frei J, Jutla J, Kramer G, Hatzakis GE, Ducharme FM, Davis GM. "Impulse oscillometry reference values in children 100 to $150 \mathrm{~cm}$ in height and 3 to 10 years of age." CHEST, vol. 128, pp. 12661273, 2005.

25. Denker M, Malmber LP, Valind S, Thorsson O, Karlsson MK, Pelkonen A, Pohjanpalo A, Haahtela T, Turpeinen M, Wollmer P. "Reference values for respiratory system impedance by using impulse oscillometry in children aged 211 years." Clin Physiol Funct Imaging, vol. 26, pp. 247-250, 2006.

26. Park JH, Yoon JW, Shin YH, Jee HM, Wee YS, Chang SJ, Sim JH, Yum HY, Han MY. "Reference values for respiratory system impedance using impulse oscillometry in healthy preschool children." Korean J Pediatr, vol. 2, pp. 64-68, 2011.

27. Lee JY, Seo J-H, Kim HY, Jung YH, Kwon J-W, Kim B-J, Kim HB, Lee S-Y, Jang GC, Song DJ, Kim WK, Shim JY, Kim H-J, Shin Y-J, Park J-W, Cho SH, Lee J-S, Hong S-J. "Reference values of impulse oscillometry and its utility in the diagnosis of asthma in young Korean children." Journal of Asthma, vol. 49, no. 8, pp. 811-816, 2012. 
28. Lai SH, Yao TC, Liao SL, Tsai MH, Hua MC, Yeh KW, Huang JL. "Reference Values of Impulse Oscillometry in Taiwanese Preschool Children." Pediatrics and Neonatology, vol. 56, pp. 165-170, 2015.

29. Ducharme FM, David M, Ducharme GR. "Pediatric reference values for respiratory resistance measured by forced oscillation." CHEST, vol. 113, pp. 1322-1328, 1998.

30. Clement J, Dumoulin B, Gubbelmans $\mathrm{R}$, Hendriks S, van de Woestijne KP. "Reference values of total respiratory resistance and reactance between 4 and $26 \mathrm{~Hz}$ in children and adolescents aged 4-20 years." Bull Eur Physiopathol Respir, vol. 23, pp. 441-448, 1987.

31. Amra B, Soltaninejad F, Golshan M. "Respiratory resistance by impulse oscillometry in healthy Iranian children aged 5-19." Iran J Allergy Asthma Immunol, vol. 7, no. 1, pp. 25-29, 2008.

32. Nowowiejska B, Tomalak W, Radlinski J, Siergiejko G, Latawiec W, Kackzmarski M. Transient reference values for impulse oscillometry for children aged 3-18 Years." Pediatric Pulmonology, vol. 43, pp. 1193-1197, 2008.

33. Gochicoa-Rangel L, Torre-Bouscoulet L, Martínez-Briseño D, RodríguezMoreno L, Cantú-González G, Vargas MH. "Values of impulse oscillometry in healthy Mexican children and adolescents." Respiratory Care, vol. 60, no. 1, pp. 119-127, 2015.

34. Hagiwara S, Mochizuki H, Muramatsu R, Koyama H, Yagi H, Nishida Y, Kobayashi T, Sakamoto N. "Reference values for Japanese children's respiratory resistance using the LMS Method." Allergology International, vol. 63, pp. 113-119, 2014.

35. Santos Schivinski CI, Seabra de Assumpcao M, Maba Goncalves R, Martins R, Godoy Bobbio T. "Reference equations for impulse oscillometry system parameters in Brazilian healthy children and adolescents." Physiotherapy vol. 101, no. 1, pp. eS645-eS646, 2015.

36. Meraz E, Nazeran H, Diong B, Goldman M. "Modeling human respiratory impedance in anglo asthmatic children." Biomedical Engineering Recent Developments, Proceeding of the Twenty Third Southern Biomedical Engineering Conference, pp. 108-113, 2007.

37. Meraz E, Nazeran H, Diong B, Nava P, Goldman M. "Normal Impulse Oscillometry (IOS) lung function parameters in adolescents residing in El Paso, TX." Biomedical Engineering Recent Developments, Proceedings of the Twenty Third Southern Biomedical Engineering Conference, vol. 18, no. 9, pp. 72, 2008. 
